\title{
Random survey of the microbial quality of bottled water in South Africa
}

\author{
Marthie M Ehlers*, Walda B van Zyl, Dobromir N Pavlov and Etienne E Müller \\ Department of Medical Virology, Institute of Pathology, University of Pretoria, PO Box 2034, Pretoria, 0001, South Africa
}

\begin{abstract}
Due to the increased demand and consumption of bottled water in South Africa, there has been a growing concern about the microbiological quality of this product. Retail outlets sell local as well as imported bottled water to consumers. The microbiological quality of 10 different ( 8 local and 2 imported) bottled water products were tested over a period of three months on days 1,30 and 90. Tests for the detection of heterotrophic plate count (HPC) bacteria, total and faecal coliform bacteria, spore-forming Clostridium perfringens, somatic and F-RNA coliphages were performed on the samples. In addition samples were analysed for three selected enteric viruses, caliciviruses, enteroviruses and rotaviruses using the reverse transcriptase-polymerase chain reaction (RT-PCR). The results indicated that $8 / 10$ of the bottled water samples analysed, met the requirements set by the South African Bureau of Standards (SABS) for HPCs in bottled water of less than 100 counts per $\mathrm{m} \ell$. However, in two bottled water samples the average HPC bacteria counts were $2.64 \times 10^{2} \mathrm{cfu} \cdot \mathrm{m}^{-1}$ and $8.89 \times 10^{3} \mathrm{cfu} \cdot \mathrm{m}^{-1}$ respectively which exceeded the recommended SABS guideline. HPC counts showed a slight variation during the three-month period in the bottled water samples. Total and faecal coliform bacteria, enterococci, $C$. perfringens, bacteriophages or enteric viruses were not detected in any of the ten bottled water samples analysed. It can be concluded that the microbial quality of eight of the ten selected bottled water samples analysed was within the acceptable limits set by the SABS guidelines and therefore, was safe for human consumption.
\end{abstract}

Keywords: bottled water, bacteria, coliphages, indicators, enteric viruses

\section{Introduction}

Bottled water can be defined as any potable water that is bottled and distributed or offered for sale and specifically intended for human consumption. The source water may be springs, municipal systems or other sources, which are considered to be of safe and sanitary quality and fit for human consumption. However, consumers should be aware that bottled water is not necessarily safer than tap water. Bottled and municipal water may contain the same microorganisms since both can originate from the same sources (Warburton, 2000). Under improper and/or prolonged storage of bottled water, bacteria can grow to levels that may be harmful to human health (Warburton, 2000). Consequently, when offered for sale to the consumer, these bottled water products should comply with all of the regulations as set by the South African Natural Bottled Water Association (SANBWA). According to SANBWA any harmful bacteria must be absent; however, these bacteria were not specified. Water from springs, wells, boreholes, municipal supplies, bottled water and other sources are known vehicles for enteric pathogens such as bacteria, parasites and viruses (Manaia et al., 1990). The presence of these micro-organisms can have an impact on the health of travellers, immuno-compromised persons and infants if bottled water is used for formula preparations.

Bottled water has been implicated as the source of outbreaks of cholera, typhoid fever as well as traveller's disease in countries such as Portugal and Spain (Blake et al., 1977; Mavridou, 1992; Warburton et al., 1992; Warburton, 2000). Recently, Norovirus (previously known as Norwalk-like viruses) sequences were detected in three European brands of mineral water (Beuret et al.,

* To whom all correspondence should be addressed.

唺+2712 319 2534; fax: +27 123255550 ; e-mail: marthie.ehlers@up.ac.za Received 23 August 2003; accepted in revised form 12 December 2003.
2002). However, controversy surrounded the accuracy of the results obtained by Beuret and co-workers (2002).

In Canada and other overseas countries stringent regulations have been implemented for the microbial quality of bottled water (Warburton et al., 1992; Warburton et al., 1998). However, in South Africa little is known about the microbiological quality of bottled water.

Heterotrophic plate count bacteria (HPC) are commonly used to assess the general microbiological quality of bottled water (WHO, 2001). Drinking water quality specifications world-wide recommend HPC limits from 100 to $500 \mathrm{cfu} \cdot \mathrm{m}^{-1}$ in tap water and $50 \mathrm{cfu} \cdot \mathrm{m}^{-1}$ in bottled water (WHO, 2001). The South African Bureau of Standards (SABS) specifies an HPC limit of less than $100 \mathrm{cfu} \cdot \mathrm{m}^{\ell^{-1}}$ for bottled water (SABS, 1996). This limit is endorsed by the Department of Health and Water Affairs. Total and faecal coliform bacteria demonstrate faecal pollution in water and food and the counts of these indicator bacteria should be $0 \mathrm{cfu} \cdot 100 \mathrm{~m}^{-1}$ in bottled natural water for consumption purposes (SABS, 1996).

Bacterial indicators do not always indicate the presence of pathogenic viruses and protozoa (Payment et al., 1985; Grabow et al., 1993; Grabow, 1996). Compared to coliform bacteria, viruses and protozoan cysts are known to be more persistent in the environment and more resistant to water treatment processes (Sobsey et al., 1995). The isolation of human enteric viruses in water meeting coliform standards, demonstrated the inadequacy of coliform bacteria to ensure virus-free water (Sobsey et al., 1995). The inability of these bacterial indicators to indicate virus-free water has prompted interest in developing an indicator system more appropriate to the human enteric viruses (Sobsey et al., 1995). Thus, coliphages (phages) have been suggested as potential indicators of the presence of enteric viruses, because of their similar structure and persistence in the environment (Kott et al., 1974; Kott, 1981; Simkova and Cervenka, 1981; Grabow et al., 1984; 
Stetler, 1994, Grabow, 1996). There are many potential applications of phages as indicators or model viruses, which include their use as indicators of sewage contamination, efficiency of water and wastewater treatment and survival of enteric viruses and bacteria in the environment (Gerba, 1987).

Enteric viruses are transmitted by the faecal-oral route and infection can be acquired through contaminated water, food or vomitus and can cause diseases such as gastro-enteritis and hepatitis (Zaoutis, 1998). Enteroviruses are among the most important viral pathogens of humans and can cause an estimated 30 million infections in the US each year (Donaldson et al., 2002). The spectrum of diseases ranges from a mild febrile illness to aseptic meningitis, hand, foot and mouth disease, myocarditis, meningoencephalitis, poliomyelitis, neonatal multi-organ failure and gastroenteritis (Muir et al., 1998; Caro et al., 2001). Rotaviruses are the most common cause of acute viral gastroenteritis in infants and young children in both developing and industrialised countries (Bishop, 1994). The symptoms associated with rotavirus infections include fever, vomiting, chronic watery non-bloody diarrhoea and abdominal pain (Bishop, 1994). Caliciviruses are a major cause of acute viral gastroenteritis, also known as winter vomiting disease, in all age groups (Berke et al., 1997). Symptoms include nausea, vomiting and diarrhoea, lasting for one to three days (Berke et al., 1997). Although the symptoms are usually mild, the large numbers of people affected have economical implications in terms of medical costs and productivity (Berke et al., 1997).

Information about the survival, type and pathogenicity of micro-organisms associated and isolated from bottled water in South Africa is crucial to public health and for the evaluation of possible health risks. Although the market for bottled water at this stage is not so large, it is the fastest growing industry in the country (Neall, 2000). Bottled water quality is of major importance for the tourist industry. People tend to see bottled water as a first-world product but it sells even better in third-world countries with their suspect potable water supplies (Neall, 2000). The objective of this study was to evaluate the microbial quality of eight local and two imported brands of bottled water using bacterial indicators, coliphages as well as selected enteric viruses.

\section{Materials and methods}

\section{Samples}

Ten different commercial bottled water (non-carbonated) products that originated from springs or boreholes were randomly selected from various retail outlets. Bottled water of the same batch was bought $(9 \times 1.5 \ell$ or $3 \times 5 \ell)$ of each type. Samples were stored at room temperature $\left(25^{\circ} \mathrm{C}\right)$ and analysis was conducted on Day 1 , after 1 month, and after 3 months.

\section{Sample analyses}

\section{$p H$}

The $\mathrm{pH}$ of each sample was determined before analysis (Crison Basic 20, Lasec).

\section{Bacterial indicators}

The detection of heterotrophic plate count bacteria HPC bacteria present in bottled water samples were determined by the pour plate ( $1 \mathrm{~m} \ell$ in triplicate) method using Plate Count Agar (PCA) (Biolab) media (WHO, 2001). HPC plates were incubated at $37^{\circ} \mathrm{C}$ for $48 \mathrm{~h}$. The number of bacteria colonies were determined and reported as colony-forming units per millilitre $\left(\mathrm{cfu} \cdot \mathrm{m} \ell^{-1}\right)$.

The detection of total and faecal coliform bacteria, enterococci and Clostridium perfringens

Total and faecal coliform bacteria were determined by passing 100 $\mathrm{m} \ell$ volumes of each sample (in triplicate) through Gelman filter units (Millipore) $(0.45 \mu \mathrm{m}$ pore size, $47 \mathrm{~mm}$ diameter). The filter membranes were placed on selective media, specific for each bacterial indicator: for the detection of total coliform bacteria on mENDO agar LES (Bacto), faecal coliform bacteria on $\mathrm{mFC}$ agar (Bacto), enterococci on mENTEROCOCCUS agar (Bacto) and $C$. perfringens on Perfringens agar (Oxoid). The Perfringens agar was supplemented with perfringens (OPSP) selective supplement A and $\mathrm{B}$ (Oxoid) for the selection of $C$. perfringens bacteria. The agar plates were aerobically incubated at $37^{\circ} \mathrm{C}$ for $24 \mathrm{~h}$ except for $C$. perfringens, which was incubated anaerobically.

\section{Bacteriophage indicators}

The qualitative presence-absence (P/A) test for the qualitative detection of low numbers of somatic and F-RNA phages in water was used for sample analysis (Grabow et al., 1993; ISO, 1995; ISO, 1998a; ISO, 1998b). Presence-absence medium was added to 500 $\mathrm{m} \ell$ of the bottled water samples for coliphage replication. Samples were incubated at $37^{\circ} \mathrm{C}$ for $24 \mathrm{~h}$. This amplification method resulted in an increase in the numbers of coliphages to a level where they could readily be detected by a standard direct plaque assay (Grabow, 2001). Samples were handled aseptically, since contamination with a single viable phage particle would lead to a false positive result.

The following host cultures were added to the P/A enrichment media and incubated at $37^{\circ} \mathrm{C}$ for $24 \mathrm{~h}$ (Grabow et al., 1997):

\section{Somatic coliphages}

- Escherichia coli strain C (ATCC 13706) mutant (WG5) (ISO, 1997)

\section{Male-specific coliphages}

- Salmonella typhimurium strain WG49 phage type 3 $\mathrm{Nal}^{\mathrm{r}}\left(F^{\prime} l a c:: T n 5\right)$ Reference: NCTC 12484 (ISO, 1995)

Assays of phages by plaque assays were conducted by the doubleagar layer method (Adams, 1959) with subsequent modifications such as performing direct qualitative spot tests of P/A on the solidified host-bacteria lawn (Grabow et al., 1997).

\section{Concentration of viruses from water samples}

Viruses were concentrated from $1 \ell$ of bottled water according to the $\mathrm{SiO}_{2}$ method described by Baggi and Peduzzi (2000). The $\mathrm{SiO}_{2}$ (Sigma) was prepared as described by Boom et al. (1990). After $1 \ell$ of the bottled water was acidified to $\mathrm{pH} 3.5$ with $1 \mathrm{M}$ acetic acid (Merck), $200 \mu \ell$ of $\mathrm{SiO}_{2}$ (Sigma) and $1 \mathrm{~m} \ell$ of $0.5 \mathrm{M} \mathrm{AlCl}_{3}$ (Sigma) were added. The samples were stirred on a magnetic stirrer for 30 min at room temperature $\left(25^{\circ} \mathrm{C}\right)$ and the $\mathrm{SiO}_{2}$ was allowed to settle for $24 \mathrm{~h}$ at $4^{\circ} \mathrm{C}$. The supernatant $(900 \mathrm{~m} \ell)$ was aspirated and the remaining solution $(100 \mathrm{~m} \ell$ ) was centrifuged at $7500 \mathrm{xg}$ (Sorvall Super T21) for 10 min to pellet the $\mathrm{SiO}_{2}$. Viruses were recovered from the pellet with $1 \mathrm{~m} \ell$ of beef extract glycine buffer (GBEB) [0.05 M glycine (Merck) and 0.5\% beef extract (Merck), $\mathrm{pH} 9]$. Samples were homogenised and incubated in an oven at $64^{\circ} \mathrm{C}$ for $10 \mathrm{~min}$. After centrifugation at $16000 \mathrm{xg}$ (Eppendorf 5415D) for 


\begin{tabular}{|l|l|l|l|l|}
\hline \multicolumn{7}{|c|}{ TABLE 1 } \\
\hline Virus & $\begin{array}{l}\text { Reaction } \\
\text { (product size, bp) }\end{array}$ & $\begin{array}{l}\text { Primer (nucleotide } \\
\text { position) }\end{array}$ & Sequence (5' - 3') & Reference \\
\hline Calici & $\begin{array}{l}\text { RT-PCR: } \\
\text { Norovirus (319) } \\
\text { Sapovirus (331) }\end{array}$ & $\begin{array}{l}\text { P290 (4568-4590) } \\
\text { P289 (4865-4886) }\end{array}$ & $\begin{array}{l}\text { GATTACTCCAAGTGGGACTCCAC } \\
\text { TGACAATGTAATCATCACCATA }\end{array}$ & Jiang et al., 1999 \\
\hline Entero & RT-PCR (414) & $\begin{array}{l}\text { EP1 (64-83) } \\
\text { EP4 (459-478) }\end{array}$ & $\begin{array}{l}\text { CGGTACCTTTGTGCGCCTGT } \\
\text { TTAGGATTAGCCGCATTCAG }\end{array}$ & Gow et al., 1991 \\
\cline { 2 - 6 } & nPCR (297) & $\begin{array}{l}\text { E1 (166-182) } \\
\text { E2 (447-463) }\end{array}$ & $\begin{array}{l}\text { AAGCACTTCTGTTTCCC } \\
\text { ATTCAGGGGCCGGAGGA }\end{array}$ & Kuan, 1997 \\
\hline Rota & RT-PCR (1,062) & $\begin{array}{l}\text { R1 (1-28) } \\
\text { END9(1036-1062) }\end{array}$ & $\begin{array}{l}\text { GGCTTTAAAAGAGAGAATTTCCGTCTGG } \\
\text { GGTCACATCATACAATTCTAATCTAAG }\end{array}$ & Le Guyader et al., 1994 \\
\cline { 2 - 6 } & nPCR (189) & $\begin{array}{l}\text { R3 (51-71) } \\
\text { Rp (220-239) }\end{array}$ & $\begin{array}{l}\text { GTATGGTATTGAATATACCAC } \\
\text { TCCATTGATCCTGTTATTGG }\end{array}$ & Le Guyader et al., 1994 \\
\hline
\end{tabular}

2 min to pellet the $\mathrm{SiO}_{2}$, the supernatant was centrifuged at 125000 $\mathrm{x} \mathrm{g}$ (Beckman TL-100 ultracentrifuge) for $1 \mathrm{~h}$ at $4^{\circ} \mathrm{C}$ to pellet the viruses. The pellet was dissolved in $120 \mu \ell$ nuclease-free water (Promega Corp., Madison, WI) and immediately used for RNA extraction.

\section{Extraction of viral RNA}

Viral RNA was extracted from the water samples using TRIzol® reagent (Invitrogen, Life Technologies, Paisley, Scotland). A total of $120 \mu \ell$ of each concentrated water sample were mixed with $500 \mu$ lof TRIzol ${ }^{\circledR}$ (Invitrogen) and incubated at room temperature $\left(25^{\circ} \mathrm{C}\right)$ for $5 \mathrm{~min}$ to permit complete dissociation of the nucleoprotein complex. Following the addition of $100 \mu \ell$ chloroform (Merck), each sample mixture was incubated for $3 \mathrm{~min}$ at room temperature $\left(25^{\circ} \mathrm{C}\right)$ and centrifuged at $12000 \mathrm{x}$ f for $15 \mathrm{~min}$ at $4^{\circ} \mathrm{C}$ (Eppendorf 5402D). The aqueous phase $(300 \mu \ell)$ was transferred to each of the $1.5 \mathrm{~m} \ell$ Eppendorf tubes (Eppendorf), containing $30 \mu \ell$ of $3 \mathrm{M}$ sodium acetate $(\mathrm{pH} 5.2)$ and $600 \mu \ell$ of absolute ethanol. The samples were incubated at $-20^{\circ} \mathrm{C}$ overnight. The samples were centrifuged at $12000 \mathrm{x}$ g for $15 \mathrm{~min}$ at $4^{\circ} \mathrm{C}$ (Eppendorf Centrifuge 5402D). Each RNA pellet was washed with $300 \mu$ of $70 \%$ ethanol (Merck) and centrifuged at $12000 \mathrm{x}$ g for $5 \mathrm{~min}$ at $4^{\circ} \mathrm{C}$ (Eppendorf Centrifuge 5402D). The pellets were briefly air-dried and dissolved in $30 \mu \ell$ of nuclease-free water (Promega). The extracted viral RNA was frozen at $-70^{\circ} \mathrm{C}$ for further analysis.

\section{Molecular detection of viruses}

Extracted RNA was used for the molecular detection of calici-, entero- and rotaviruses. All RT-PCR reagents were obtained from Promega. The amplified RT-PCR and nested PCR products were separated using 2\% agarose (Seakem LE Agarose, Bioproducts, USA) gel electrophoresis in Tris-borate-EDTA (TBE) buffer (Medicell Primo gel apparatus, Holbrook, NY). A 100 bp DNA ladder (Promega) was used to determine the size of the products.

Caliciviruses: The RT-PCR method of Jiang et al. (1999) was used to determine the presence of both genera, Noro- and Sapoviruses (previously known as Norwalk-like and Sapporo-like, respectively) of caliciviruses in the bottled water samples. $10 \mu \ell$ of extracted RNA was added to the following reverse transcription polymerase chain reaction (RT-PCR) mix: $10 \mathrm{mM}$ Tris-HCl (pH 9), $50 \mathrm{mM} \mathrm{KCl}, 2 \mathrm{mM} \mathrm{MgCl}, 0.2$ mM dNTP's, 100 pmol each of primers P289 and P290 (Table 1), 10 U AMV-reverse transcriptase and $2.5 \mathrm{U}$ Taq DNA polymerase. The reaction was incubated at $42^{\circ} \mathrm{C}$ for $1 \mathrm{~h}$ and at $94^{\circ} \mathrm{C}$ for $3 \mathrm{~min}$. The cycling programme (Techne Genius thermocycler) included 40 cycles at $94^{\circ} \mathrm{C}$ for $30 \mathrm{~s}, 49^{\circ} \mathrm{C}$ for $80 \mathrm{~s}$ and $72^{\circ} \mathrm{C}$ for $60 \mathrm{~s}$. A final extension of $72^{\circ} \mathrm{C}$ for $10 \mathrm{~min}$ was included.

Enteroviruses: The possible presence of enteroviruses in the bottled water samples was determined according to the methods of Gow et al. (1991) and Kuan (1997). A Promega Access RT-PCR System (Promega) was used for the reverse transcription and PCR amplification of enteroviral RNA. A $50 \mu \ell$ reaction volume, containing the following was prepared: AMV/Tfl reaction buffer (1x), $0.2 \mathrm{mM}$ dNTP mix, 50 pmol each of primers EP1 and EP4 (Table 1), $1.5 \mathrm{mM} \mathrm{MgSO}_{4}, 5 \mathrm{U}$ of AMV reverse transcriptase and $5 \mathrm{U}$ of Tfl DNA polymerase. The reaction was incubated at $49^{\circ} \mathrm{C}$ for $45 \mathrm{~min}$ and then subjected to 30 amplification cycles consisting of $60 \mathrm{~s}$ at $94^{\circ} \mathrm{C}, 60 \mathrm{~s}$ at $55^{\circ} \mathrm{C}$ and $60 \mathrm{~s}$ at $72^{\circ} \mathrm{C}$ (Hybaid OmniGene Thermocycler). The final extension step was performed for $7 \mathrm{~min}$ at $72^{\circ} \mathrm{C}$. A nested PCR was conducted by adding $1 \mu \ell$ of the amplified product to $49 \mu \ell$ of the PCR mixture. The PCR mixture contained the following: $10 \mathrm{mM}$ Tris- $\mathrm{HCl}(\mathrm{pH}$ 9), $50 \mathrm{mM} \mathrm{KCl}, 1.5$ $\mathrm{mM} \mathrm{MgCl}, 0.2 \mathrm{mM}$ dNTP mix, 50 pmol each of primers E1 and E2 (Table 1) and $2.5 \mathrm{U}$ of Taq DNA polymerase. Cycling was carried out 35 times with denaturation at $94^{\circ} \mathrm{C}$ for $60 \mathrm{~s}$, annealing at $45^{\circ} \mathrm{C}$ for $60 \mathrm{~s}$ and extension at $72^{\circ} \mathrm{C}$ for $60 \mathrm{~s}$ (Hybaid OmniGene thermocycler).

Rotaviruses: The presence of rotaviruses was determined according to the method of Baggi and Peduzzi (2000). Primers R1, END9, $\mathrm{R} 3$ and Rp were used for the amplification of sequences from the VP7 gene of Group A rotaviruses (Le Guyader et al., 1994) (Table 1). After denaturation of extracted RNA at $97^{\circ} \mathrm{C}$ for $5 \mathrm{~min}$, the samples were immediately cooled on ice. The denatured RNA 
TABLE 2

Bacterial analysis of bottled water samples A-J during the 3-month period

\begin{tabular}{|c|c|c|c|c|c|c|c|}
\hline Sample & Days & $\mathrm{pH}$ & $\begin{array}{c}\text { HPC } \\
\left(\mathrm{cfu} \cdot \mathrm{m}^{-1}\right)\end{array}$ & $\begin{array}{c}\text { Entero- } \\
\text { cocci } \\
\left(\mathrm{cfu} \cdot 100 \mathrm{~m} \ell^{-1}\right)\end{array}$ & $\begin{array}{c}\text { Total } \\
\text { coliform } \\
\text { bacteria } \\
\left(\mathrm{cfu} \cdot 100 \mathrm{~m} \ell^{-1}\right)\end{array}$ & $\begin{array}{c}\text { Faecal } \\
\text { coliform } \\
\text { bacteria } \\
\left(\text { cfu·100 } \mathrm{m}^{-1}\right)\end{array}$ & $\begin{array}{c}\text { Clostri- } \\
\text { dium per- } \\
\text { fringens } \\
\text { (cfu-100 m } \ell^{-1} \text { ) }\end{array}$ \\
\hline A & $\begin{array}{c}1 \\
30 \\
90\end{array}$ & $\begin{array}{l}6.36 \\
6.80 \\
6.08\end{array}$ & $\begin{array}{l}2 \\
0 \\
2\end{array}$ & $\begin{array}{l}0 \\
0 \\
0\end{array}$ & $\begin{array}{l}0 \\
0 \\
0\end{array}$ & $\begin{array}{l}0 \\
0 \\
0\end{array}$ & $\begin{array}{l}0 \\
0 \\
0\end{array}$ \\
\hline $\begin{array}{l}\text { B } \\
\text { (Imported) }\end{array}$ & $\begin{array}{c}1 \\
30 \\
90\end{array}$ & $\begin{array}{l}7.64 \\
7.64 \\
7.00\end{array}$ & $\begin{array}{l}6 \\
3 \\
5\end{array}$ & $\begin{array}{l}0 \\
0 \\
0\end{array}$ & $\begin{array}{l}0 \\
0 \\
0\end{array}$ & $\begin{array}{l}0 \\
0 \\
0\end{array}$ & $\begin{array}{l}0 \\
0 \\
0\end{array}$ \\
\hline $\mathrm{C}$ & $\begin{array}{c}1 \\
30 \\
90\end{array}$ & $\begin{array}{l}6.77 \\
6.91 \\
6.71\end{array}$ & $\begin{array}{l}6 \\
0 \\
2\end{array}$ & $\begin{array}{l}0 \\
0 \\
0\end{array}$ & $\begin{array}{l}0 \\
0 \\
0\end{array}$ & $\begin{array}{l}0 \\
0 \\
0\end{array}$ & $\begin{array}{l}0 \\
0 \\
0\end{array}$ \\
\hline $\begin{array}{l}\text { D } \\
\text { (Imported) }\end{array}$ & $\begin{array}{c}1 \\
30 \\
90\end{array}$ & $\begin{array}{l}7.59 \\
7.74 \\
7.10\end{array}$ & $\begin{array}{c}10 \\
5 \\
3\end{array}$ & $\begin{array}{l}0 \\
0 \\
0\end{array}$ & $\begin{array}{l}0 \\
0 \\
0\end{array}$ & $\begin{array}{l}0 \\
0 \\
0\end{array}$ & $\begin{array}{l}0 \\
0 \\
0\end{array}$ \\
\hline $\mathrm{E}$ & $\begin{array}{c}1 \\
30 \\
90\end{array}$ & $\begin{array}{l}7.45 \\
7.58 \\
7.50\end{array}$ & $\begin{array}{c}11 \\
1 \\
1\end{array}$ & $\begin{array}{l}0 \\
0 \\
0\end{array}$ & $\begin{array}{l}0 \\
0 \\
0\end{array}$ & $\begin{array}{l}0 \\
0 \\
0\end{array}$ & $\begin{array}{l}0 \\
0 \\
0\end{array}$ \\
\hline $\mathrm{F}$ & $\begin{array}{c}1 \\
30 \\
90\end{array}$ & $\begin{array}{l}7.53 \\
7.67 \\
7.40\end{array}$ & $\begin{array}{l}1 \\
3 \\
1\end{array}$ & $\begin{array}{l}0 \\
0 \\
0\end{array}$ & $\begin{array}{l}0 \\
0 \\
0\end{array}$ & $\begin{array}{l}0 \\
0 \\
0\end{array}$ & $\begin{array}{l}0 \\
0 \\
0\end{array}$ \\
\hline G & $\begin{array}{c}1 \\
30 \\
90\end{array}$ & $\begin{array}{l}8.19 \\
8.05 \\
7.37\end{array}$ & $\begin{array}{c}240 \\
540 \\
11\end{array}$ & $\begin{array}{l}0 \\
0 \\
0\end{array}$ & $\begin{array}{l}0 \\
0 \\
0\end{array}$ & $\begin{array}{l}0 \\
0 \\
0\end{array}$ & $\begin{array}{l}0 \\
0 \\
0\end{array}$ \\
\hline $\mathrm{H}$ & $\begin{array}{c}1 \\
30 \\
90\end{array}$ & $\begin{array}{l}7.18 \\
6.95 \\
7.17\end{array}$ & $\begin{array}{c}13100 \\
2580 \\
11000\end{array}$ & $\begin{array}{l}0 \\
0 \\
0\end{array}$ & $\begin{array}{l}0 \\
0 \\
0\end{array}$ & $\begin{array}{l}0 \\
0 \\
0\end{array}$ & $\begin{array}{l}0 \\
0 \\
0\end{array}$ \\
\hline I & $\begin{array}{c}1 \\
30 \\
90\end{array}$ & $\begin{array}{l}7.71 \\
7.76 \\
7.50\end{array}$ & $\begin{array}{l}3 \\
0 \\
6\end{array}$ & $\begin{array}{l}0 \\
0 \\
0\end{array}$ & $\begin{array}{l}0 \\
0 \\
0\end{array}$ & $\begin{array}{l}0 \\
0 \\
0\end{array}$ & $\begin{array}{l}0 \\
0 \\
0\end{array}$ \\
\hline $\mathrm{J}$ & $\begin{array}{c}1 \\
30 \\
90\end{array}$ & $\begin{array}{l}7.21 \\
7.00 \\
7.41\end{array}$ & $\begin{array}{l}2 \\
2 \\
4\end{array}$ & $\begin{array}{l}0 \\
0 \\
0\end{array}$ & $\begin{array}{l}0 \\
0 \\
0\end{array}$ & $\begin{array}{l}0 \\
0 \\
0\end{array}$ & $\begin{array}{l}0 \\
0 \\
0\end{array}$ \\
\hline
\end{tabular}

was added to the following PCR mix: $10 \mathrm{mM}$ Tris- $\mathrm{HCl}$ (pH 9), 50 $\mathrm{mM} \mathrm{KCl}, 1 \mathrm{mM} \mathrm{MgCl}, 0.2 \mathrm{mM}$ dNTP's, 25 pmol each of primers R1 and End9 (Table 1), 10 U AMV-reverse transcriptase and 2.5 $\mathrm{U}$ Taq DNA polymerase. The RT-PCR reactions were incubated for $30 \mathrm{~min}$ at $42^{\circ} \mathrm{C}$ followed by $60 \mathrm{~s}$ at $94^{\circ} \mathrm{C}, 120 \mathrm{~s}$ at $55^{\circ} \mathrm{C}$ and 60 s at $72^{\circ} \mathrm{C}$, for a total of 25 cycles. A final extension at $72^{\circ} \mathrm{C}$ for 7 min concluded the RT-PCR amplification step. A $2 \mu \ell$ volume of the RT-PCR amplification products was added to the following PCR mix for the nested PCR: $10 \mathrm{mM}$ Tris- $\mathrm{HCl}(\mathrm{pH} 9), 50 \mathrm{mM} \mathrm{KCl}$, $1.5 \mathrm{mM} \mathrm{MgCl}, 0.2 \mathrm{mM}$ dNTP's, 25 pmol each of primers R3 and Rp (Table 1) and $2.5 \mathrm{U}$ Taq DNA polymerase. After initial denaturation of $120 \mathrm{~s}$ at $94^{\circ} \mathrm{C}$, the following cycling conditions were performed: $30 \mathrm{~s}$ at $94^{\circ} \mathrm{C}, 30 \mathrm{~s}$ at $50^{\circ} \mathrm{C}$ and $30 \mathrm{~s}$ at $72^{\circ} \mathrm{C}$ for 3 cycles, followed by 27 cycles of $15 \mathrm{~s}$ at $94^{\circ} \mathrm{C}, 15 \mathrm{~s}$ at $50^{\circ} \mathrm{C}$ and 20 s at $72^{\circ} \mathrm{C}$. A final extension at $72^{\circ} \mathrm{C}$ for 7 min concluded the nested PCR amplification step (Techne Genius thermocycler).

\section{Results and discussion}

The microbial quality of bottled (non-carbonated) water is of great interest as many consumers use it as an alternative to municipal water and consider it to be better and safer (Mavridou, 1992). Bottled water is generally of good quality for drinking, but if not properly protected during bottling and transit, could be a subject of 
contamination (Mavridou, 1992).

Despite the potential for contamination of source water, there have been only a few waterborne outbreaks associated with bottled water (Warburton, 1993; Warburton et al., 1998). According to epidemiological evidence the waterborne exposure route is important in the dissemination of viruses to human hosts (Biziagos et al., 1988; Beuret et al., 2002). However, to date bottled water has not been clearly identified as a source of infection with enteric viruses such as hepatitis A or Noroviruses (Biziagos et al., 1988; Beuret et al., 2002).

The bottled water examined in this study showed heterotrophic plate counts (HPCs) which were within the established quality guidelines for bottled water of less than $100 \mathrm{cfu} \cdot \mathrm{m} \ell^{-1}$ (SABS, 1996) (Table 2). Bottled water samples marked A, B, C, F, I and J had HPCs less than $10 \mathrm{cfu} \cdot \mathrm{m} \ell^{-1}$, whereas samples D and E had HPCs less than $20 \mathrm{cfu} \cdot \mathrm{m}^{-1}$. However, two local brands $(\mathrm{G}$ and $\mathrm{H})$ displayed HPCs that were above the excepted limit indicated by the SABS standard (SABS, 1996). Heterotrophic plate counts for bottled water brand $\mathrm{G}$ ranged from $1.1 \times 10^{2} \mathrm{cfu} \cdot \mathrm{m}^{-1}$ to $5.4 \times 10^{2}$ $\mathrm{cfu} \cdot \mathrm{ml}^{-1}$ with a mean value of $2.64 \times 10^{2} \mathrm{cfu} \cdot \mathrm{m}^{-1}$. The HPCs for bottled water brand $\mathrm{H}$ ranged from $2.58 \times 10^{3} \mathrm{cfu} \cdot \mathrm{m} \ell^{-1}$ to $1.3 \times 10^{4}$ $\mathrm{cfu} \cdot \mathrm{m}^{-1}$ with a mean value of $8.89 \times 10^{3} \mathrm{cfu} \cdot \mathrm{m}^{\ell^{-1}}$.

The South African Department of Health has a health risk range for HPC bacteria of no risk for counts less than $100 \mathrm{cfu} \cdot \mathrm{m} \ell^{-1}$ and greater risk for counts above $10000 \mathrm{cfu} \cdot \mathrm{m}^{\ell^{-1}}$. Thus, the South African Bureau of Standards (SABS) specifies a HPC limit of less than $100 \mathrm{cfu} \cdot \mathrm{m}^{-1}$ for bottled water (SABS, 1996). This limit is endorsed by the South African Departments of Health and Water Affairs and is in line with specifications and recommendations in the rest of the world (WHO, 2001).

Bottled (non-carbonated) water generally have high HPCs, since the elimination of micro-organisms by disinfection or sterilisation is not permitted (Anon, 1980; Manaia et al., 1990). The presence of high numbers of heterotrophic bacteria in bottled water may be due to the natural microbial flora of the source water. These bacteria can multiply after bottling, resulting in high numbers of HPCs (Li et al., 2001). While bottled water may initially meet bacteria standards, the lack of a residual disinfectant (chlorine) and prolonged periods of storage at room temperature or higher may result in elevated HPC bacteria counts by the time the water is consumed (Li et al., 2001). Microbial numbers reach a peak after a week of storage and remain fairly constant thereafter ( $\mathrm{Li}$ et al., 2001).

Recent studies have identified several heterotrophic bacteria as being common in bottled water; these included genera such as: Achromobacter, Acinetobacter, Aeromonas, Alcaligenes, Arthrobacter, Caulobacter, Corynebacterium, Flavobacterium and Pseudomonas (Manaia et al., 1990). However, some of these genera contain species that have been known as opportunistic pathogens. Although HPC bacteria have been considered harmless, several epidemiological studies conducted in countries such as Canada and the USA suggested the potential health risk associated with HPC bacteria present in drinking water, which comply to water quality standards (Payment et al., 1994; Edberg et al., 1996; Grabow, 1996; Rusin et al., 1997; Pavlov et al., 2004). In studies on filtered and non-filtered tap water conducted by Payment et al. (1991a; 1991b), the researchers found an association between high numbers of HPC bacteria and gastroenteritis. According to a study conducted on treated drinking water in South Africa, some members of the HPC bacteria produce virulence factors and therefore, may act as opportunistic pathogens (Pavlov et al., 2004). The components of the community that are specifically at risk of HPC infections include the very young and the elderly with weakened immune systems, as well as individuals with immuno-compromising diseases such as AIDS, and patients that underwent organ transplantation, chemotherapy, and pregnant women. However, it was not part of this study to identify the heterotrophic bacteria isolated from the bottled water samples but it is possible that the samples may include potentially pathogenic species of the abovementioned genera.

Strict standards exist that prohibit the sale of bottled water containing coliforms, faecal coliforms, faecal streptococci, sulphide-reducing clostridial sporeformers, Pseudomonas aeruginosa and pathogens (Anon, 1980). The fact that neither Clostridium perfringens, enterococci, total coliform bacteria nor faecal coliform bacteria were found in any of the ten bottled water samples in this study indicated the absence of faecal contamination in these samples (Table 2). However, studies have indicated that high counts of E. coli $\left(10^{5}\right.$ to $\left.10^{7} \mathrm{cfu} \cdot \mathrm{m}^{-1}\right)$ in bottled water could not be detected within four days (Ducluzeau et al., 1976) or 20 to $30 \mathrm{~d}$ (Moreira et al., 1994). This absence of coliform bacteria might be due to die-off in the bottles during storage.

The bottled water samples were tested for the presence of bacteriophages such as somatic and F-RNA coliphages. The presence of phages, which is typically associated with human and animal excreta, indicates the potential presence of enteric viruses (Grabow, 1986; Grabow, 2001). However, in this study somatic and F-RNA coliphages were not detected (Table 3), which indicated the possible absence of enteric viruses in the tested bottled water samples.

The WHO Scientific Group has concluded that the presence of even a few enteric viruses in drinking water poses a human health threat (WHO, 1979). According to the SABS standard (2001) for drinking water, enteric viruses must be absent from $100 \ell$ of water. Therefore, the ten bottled water samples were further analysed for the presence of enteric viruses such as caliciviruses, enteroviruses and rotaviruses. Recent developments in molecular detection technology made it possible to identify viruses by non-culture-based methods such as the polymerase chain reaction (PCR) (Muir et al., 1998; Donaldson et al., 2002). Reverse transcription-polymerase chain reaction (RT-PCR) assays have been developed to detect viral RNA directly from samples because of the high sensitivity for small amounts of RNA (Casas et al., 2001).

The presence of enteroviruses in raw and treated drinking water, which comply with specifications for treatment and counts of indicator organisms has been documented (Abbaszadegan et al., 1999; Grabow et al., 2000). The presence of caliciviruses in European bottled water brands (Beuret et al., 2002) and of rotaviruses in drinking water supplies in Colorado, USA has been described (Hopkins et al., 1984). However, no calici-, entero- or rotaviruses were detected with PCR in this study in any of the bottled water samples that were analysed (Table 3).

\section{Conclusions}

The study indicated that eight local and two imported brands of bottled water were free of total and faecal coliform bacteria, enterococci, $C$. perfringens, bacteriophages and selected enteric viruses. Levels of HPC bacteria that exceeded the specifications of the SABS were, however, detected in two of the ten brands analysed (Brands $\mathrm{G}$ and $\mathrm{H}$ ). The results obtained in this study were comparable and in agreement with similar reports by other researchers such as Manaia et al. (1990), Mavridou (1992), Tsai and $\mathrm{Yu}$ (1997) indicating that bottled water generally complied with current drinking water legislations. Microbial contamination of bottled natural water is most likely to occur due to improperly 


\begin{tabular}{|c|c|c|c|c|c|c|c|}
\hline \multicolumn{8}{|c|}{$\begin{array}{c}\text { TABLE } 3 \\
\begin{array}{c}\text { Bacteriophage and selected enteric viral analysis of bottled water samples A-J } \\
\text { during the 3-month period }\end{array}\end{array}$} \\
\hline \multirow[t]{2}{*}{ Sample } & \multirow[t]{2}{*}{ Days } & \multirow[t]{2}{*}{$\mathrm{pH}$} & \multicolumn{2}{|c|}{$\begin{array}{c}\text { Coliphages } P / A \text { in } \\
500 \mathrm{~m} \ell\end{array}$} & \multicolumn{3}{|c|}{ PCR per 1 litre } \\
\hline & & & Somatic & F-RNA & $\begin{array}{l}\text { Calici- } \\
\text { virus }\end{array}$ & $\begin{array}{l}\text { Entero- } \\
\text { virus }\end{array}$ & $\begin{array}{l}\text { Rota- } \\
\text { virus }\end{array}$ \\
\hline A & $\begin{array}{c}1 \\
30 \\
90\end{array}$ & $\begin{array}{l}6.36 \\
6.80 \\
6.08\end{array}$ & $\begin{array}{l}\text { A } \\
\text { A } \\
\text { A }\end{array}$ & $\begin{array}{l}\text { A } \\
\text { A } \\
\text { A }\end{array}$ & $\begin{array}{l}\text { A } \\
\text { A } \\
\text { A }\end{array}$ & $\begin{array}{l}\text { A } \\
\text { A } \\
\text { A }\end{array}$ & $\begin{array}{l}\text { A } \\
\text { A } \\
\text { A }\end{array}$ \\
\hline $\begin{array}{l}\text { B } \\
\text { (Imported) }\end{array}$ & $\begin{array}{c}1 \\
30 \\
90\end{array}$ & $\begin{array}{l}7.64 \\
7.64 \\
7.00\end{array}$ & $\begin{array}{l}\text { A } \\
\text { A } \\
\text { A }\end{array}$ & $\begin{array}{l}\text { A } \\
\text { A } \\
\text { A }\end{array}$ & $\begin{array}{l}\text { A } \\
\text { A } \\
\text { A }\end{array}$ & $\begin{array}{l}\text { A } \\
\text { A } \\
\text { A }\end{array}$ & $\begin{array}{l}\text { A } \\
\text { A } \\
\text { A }\end{array}$ \\
\hline $\mathrm{C}$ & $\begin{array}{c}1 \\
30 \\
90\end{array}$ & $\begin{array}{l}6.77 \\
6.91 \\
6.71\end{array}$ & $\begin{array}{l}\text { A } \\
\text { A } \\
\text { A }\end{array}$ & $\begin{array}{l}\text { A } \\
\text { A } \\
\text { A }\end{array}$ & $\begin{array}{l}\text { A } \\
\text { A } \\
\text { A }\end{array}$ & $\begin{array}{l}\text { A } \\
\text { A } \\
\text { A }\end{array}$ & $\begin{array}{l}\text { A } \\
\text { A } \\
\text { A }\end{array}$ \\
\hline $\begin{array}{l}\text { D } \\
\text { (Imported) }\end{array}$ & $\begin{array}{c}1 \\
30 \\
90\end{array}$ & $\begin{array}{l}7.59 \\
7.74 \\
7.10\end{array}$ & $\begin{array}{l}\text { A } \\
\text { A } \\
\text { A }\end{array}$ & $\begin{array}{l}\text { A } \\
\text { A } \\
\text { A }\end{array}$ & $\begin{array}{l}\text { A } \\
\text { A } \\
\text { A }\end{array}$ & $\begin{array}{l}\text { A } \\
\text { A } \\
\text { A }\end{array}$ & $\begin{array}{l}\text { A } \\
\text { A } \\
\text { A }\end{array}$ \\
\hline E & $\begin{array}{c}1 \\
30 \\
90\end{array}$ & $\begin{array}{l}7.45 \\
7.58 \\
7.50\end{array}$ & $\begin{array}{l}\text { A } \\
\text { A } \\
\text { A }\end{array}$ & $\begin{array}{l}\text { A } \\
\text { A } \\
\text { A }\end{array}$ & $\begin{array}{l}\text { A } \\
\text { A } \\
\text { A }\end{array}$ & $\begin{array}{l}\text { A } \\
\text { A } \\
\text { A }\end{array}$ & $\begin{array}{l}\mathrm{A} \\
\mathrm{A} \\
\mathrm{A}\end{array}$ \\
\hline $\mathrm{F}$ & $\begin{array}{c}1 \\
30 \\
90\end{array}$ & $\begin{array}{l}7.53 \\
7.67 \\
7.40\end{array}$ & $\begin{array}{l}\text { A } \\
\text { A } \\
\text { A }\end{array}$ & $\begin{array}{l}\text { A } \\
\text { A } \\
\text { A }\end{array}$ & $\begin{array}{l}\text { A } \\
\text { A } \\
\text { A }\end{array}$ & $\begin{array}{l}\text { A } \\
\text { A } \\
\text { A }\end{array}$ & $\begin{array}{l}\text { A } \\
\text { A } \\
\text { A }\end{array}$ \\
\hline $\mathrm{G}$ & $\begin{array}{c}1 \\
30 \\
90\end{array}$ & $\begin{array}{l}8.19 \\
8.05 \\
7.37\end{array}$ & $\begin{array}{l}\text { A } \\
\text { A } \\
\text { A }\end{array}$ & $\begin{array}{l}\text { A } \\
\text { A } \\
\text { A }\end{array}$ & $\begin{array}{l}\text { A } \\
\text { A } \\
\text { A }\end{array}$ & $\begin{array}{l}\text { A } \\
\text { A } \\
\text { A }\end{array}$ & $\begin{array}{l}\text { A } \\
\text { A } \\
\text { A }\end{array}$ \\
\hline $\mathrm{H}$ & $\begin{array}{c}1 \\
30 \\
90\end{array}$ & $\begin{array}{l}7.18 \\
6.95 \\
7.17\end{array}$ & $\begin{array}{l}\text { A } \\
\text { A } \\
\text { A }\end{array}$ & $\begin{array}{l}\text { A } \\
\text { A } \\
\text { A }\end{array}$ & $\begin{array}{l}\text { A } \\
\text { A } \\
\text { A }\end{array}$ & $\begin{array}{l}\text { A } \\
\text { A } \\
\text { A }\end{array}$ & $\begin{array}{l}\text { A } \\
\text { A } \\
\text { A }\end{array}$ \\
\hline I & $\begin{array}{c}1 \\
30 \\
90\end{array}$ & $\begin{array}{l}7.71 \\
7.76 \\
7.50\end{array}$ & $\begin{array}{l}\text { A } \\
\text { A } \\
\text { A }\end{array}$ & $\begin{array}{l}\text { A } \\
\text { A } \\
\text { A }\end{array}$ & $\begin{array}{l}\text { A } \\
\text { A } \\
\text { A }\end{array}$ & $\begin{array}{l}\text { A } \\
\text { A } \\
\text { A }\end{array}$ & $\begin{array}{l}\text { A } \\
\text { A } \\
\text { A }\end{array}$ \\
\hline $\mathrm{J}$ & $\begin{array}{c}1 \\
30 \\
90\end{array}$ & $\begin{array}{l}7.21 \\
7.00 \\
7.41\end{array}$ & $\begin{array}{l}\text { A } \\
\text { A } \\
\text { A }\end{array}$ & $\begin{array}{l}\text { A } \\
\text { A } \\
\text { A }\end{array}$ & $\begin{array}{l}\text { A } \\
\text { A } \\
\text { A }\end{array}$ & $\begin{array}{l}\text { A } \\
\text { A } \\
\text { A }\end{array}$ & $\begin{array}{l}\text { A } \\
\text { A } \\
\text { A }\end{array}$ \\
\hline
\end{tabular}

cleaned equipment and bottles, failure of ozonation or UV equipment or due to contamination of the water by workers. Future studies may address the microbiological quality of source water used for the bottling of local mineral water brands as well as the detection of virulence factors associated with potentially pathogenic HPC bacteria

\section{Acknowledgements}

The authors would like to thank the Research Committee of the University of Pretoria for funding this project.

\section{References}

ADAMS MH (1959) Bacteriophages. Interscience, New York.

ABBASZADEGAN M, STEWART P and LECHEVALLIER M (1999) A strategy for the detection of viruses in ground water by PCR. Appl. Environ. Microbiol. 65 444-449.

ANON (1980) Directive du Conseil du 15 Juillet 1980 relative au rapprochement des legislation des États membres concernant l'exploitation et mise dans le commerce des eaux minerales naturelles. (80/777/CEE) Journal Officiel des Communautes Européennes No. L229/1-10.

BAGGI F and PEDUZZI R (2000) Genotyping of rotaviruses in environmental water and stool samples in Southern Switzerland by nucleotide 
sequencing analysis of 189 base pairs at the 5' end of the VP7 gene. J. Clin. Microbiol. 38 3681-3685.

BERKE T, GOLDING B, JIANG X, CUBITT DW, WOLFAARDT M, SMITH AW and MATSON DO (1997) Phylogenetic analysis of the Caliciviridae. J. Med. Virol. 52 419-424.

BEURET C, KOHLER D, BAUMGARTNER A and LÜTHI TM (2002) Norwalk-like virus sequences in mineral waters: one-year monitoring of three brands. ASM 68 1925-1931.

BISHOP RF (1994) Natural history of human rotavirus infections. In: Kapikian AZ (ed.) Viral Infections of the Gastrointestinal Tract ( $2^{\text {nd }}$ edn.). Marcel Dekker Inc. New York.

BIZIAGOS E, PASSAGOT J, CANCE JM and DELOINCE R (1988) Long-term survival of hepatitis A and poliovirus type 1 in mineral water. Appl. Environ. Microbiol. 54 2705-2709.

BLAKEPA, ROSENBERG ML, FLORENCIA J, COSTA JB, QUINTINO LDP and GANGAROSA EJ (1977) Cholera in Portugal, 1974. II Transmission by bottled mineral water. Am. J. Epidemiol. $105344-$ 348.

BOOM R, SOR CJA, SALILMANS MMM, JANSEN CL, WERTHEIM VAN DILLEN PME and VAN DER NOORAA J (1990) Rapid and simple method for purification of nucleic acids. J. Clin. Microbiol. 28 495-503.

CARO V, GUILLOT S, DELPEYROUX F and CRAINIC R (2001) Molecular strategy for "serotyping" of human enteroviruses. J. Gen. Virol. 82 79-91.

CASAS I, PALACIOS GF, TRALLERO G, CISTERNA D, FREIRE MC and TENORIO A (2001) Molecular characterisation of human enteroviruses in clinical samples: Comparison between VP2, VP1 and RNA polymerase regions using RT nested PCR assays and direct sequencing of products. J. Med. Virol. 65 138-148.

DONALDSON KA, GRIFFIN DW and PAUL JH (2002) Detection, quantitation and identification of enteroviruses from surface waters and sponge tissue from the Florida Keys using real-time RT-PCR. Water Res. 36 2505-2514.

DUCLUZEAU R, BOCHAND JM and DUFRESNE S (1976) Longevity of various bacterial strains of intestinal origin in gas-free mineral water. Eur. J. Appl. Microbiol. 3 227-236.

EDBERG SC, GALLO P and KONTNICK C (1996) Analysis of the virulence characteristics of bacteria isolated from bottled, water cooler, and tap water. Microb. Ecol. Health. Dis. 9 67-77.

GERBA CP (1987) Phages as Indicators of Faecal Pollution. In: Goyal SM, Gerba CP and Bitton G (eds.) Phage Ecology. John Wiley and Sons, New York. 45-74.

GOW JW, BEHAN WMH, CLEMENTS GB, WOODALL C, RIDING M and BEHAN PO (1991) Enteroviral RNA sequences detected by polymerase chain reaction in muscle of patients with postviral fatigue syndrome. Br. Med. J. 302 692-696.

GRABOW WOK, COUBROUGH P, NUPEN EM and BATEMAN BW (1984) Evaluation of coliphages as indicators of the virological quality of sewage-polluted water. Water SA 10 7-14.

GRABOW WOK (1986) Indicator systems for assessment of the virological safety of treated drinking water. Water Sci. Technol. 18 159-165.

GRABOW WOK, HOLTZHAUSEN CS and DE VILLIERS JC (1993) Research on Bacteriophages as Indicators of Water Quality. WRC Report No 321/1/93. Water Research Commission, Pretoria. 147 pp.

GRABOW WOK (1996) Waterborne diseases: Update on water quality assessment and control. Water SA 22 193-202.

GRABOW WOK, VREY A, UYS M and DE VILLIERS (1997) Evaluation of the Application of Bacteriophages as Indicators of Water Quality. 1 January - 31 December 1995. WRC Report No 540/1/98. Water Research Commission, Pretoria.

GRABOW WOK, TAYLOR MB and DE VILLIERS JC (2000) New methods for the detection of viruses: Call for review of drinking water quality guidelines. Water Sci. Technol. 43 1-8.

GRABOW WOK (2001) Bacteriophages: Update on application as models for viruses in water. Water SA 27 251-268.

HOPKINS RS, GASPARD B, WILLIAMS FP, KARLIN RJ, CUKOR G and BLACKLOW NR (1984) A community waterborne gastroenteritis outbreak: Evidence for rotavirus as the agent. Am. J. Public Health 74 263-265.
ISO (1995) Water Quality - Detection and Enumeration of Bacteriophages. Part 1: Enumeration of F-specific RNA Bacteriophages. International Organization for Standardization, Geneva. ISO 10705-1:1995. 15 pp.

ISO (1997) Water Quality - Detection and Enumeration of Bacteriophages. Part 2: Enumeration of Somatic Coliphages - Revised Version. International Organization for Standardization, Geneva. ISO/DIS 10705-2:1997

ISO (1998a) Water Quality - Detection and Enumeration of Bacteriophages. Part 2: Enumeration of Somatic Coliphages. International Organization for Standardization, Geneva. ISO/DIS 10705-2.2. 1995. 17 pp.

ISO (1998b) Water Quality - Detection and Enumeration of Bacteriophages. Part 4: Enumeration of Somatic Coliphages. International Organization for Standardization, Geneva. ISO/CD 10705-4. 29 pp.

JIANG X, HUANG PW, ZHONG WM, FARKAS T, CUBITT DW and MATSON DO (1999) Design and evaluation of a primer pair that detects both Norwalk- and Sapporo-like caliciviruses by RT-PCR. J. Virol. Methods 83 145-154.

KOTT Y, ROZE N, SPERBER S and BETZER N (1974) Bacteriophages as viral pollution indicators. Water Res. 8 165-171.

KOTT Y (1981) Viruses and bacteriophages. Sci. Total Environ. 18 13-23. KUAN M (1997) Detection and rapid differentiation of human enteroviruses following genomic amplification. J. Clin. Micro. 35 2598-2601.

LE GUYADER F, DU BOIS E, MENARD D and POMMEPUY M (1994) Detection of hepatitis A virus, rotavirus and enterovirus in naturally contaminated shellfish and sediment by reverse transcription-sedinested PCR. Appl. Environ. Microbiol. 60 3665-3671.

LI WMK, LACROIX B and POWELL DA (2001) The microbiological safety of bottled water in Canada. http://www.foodsafetynetwork.ca/ food/microbiological safety of bottle.htm.

MANAIA CM, NUNES OC, MORAIS PV and DA COSTA MS (1990) Heterotrophic plate counts and the isolation of bacteria from mineral waters on selective and enrichment media. J. Appl. Bacteriol. 69 871-876.

MAVRIDOU A (1992) Study of the bacterial flora of a non-carbonated natural mineral water. J. Appl. Bacteriol. 73 355-361.

MOREIRA L, AGOSTINHO P, MORAIS PV and DA COSTA MS (1994) Survival of allochthonous bacteria in still mineral water bottled in polyvinyl chloride (PVC) and glass. J. Appl. Bacteriol. 77 334-339.

MUIR P, KÄMMERER U, KORN K, MULDERS MN, PÖYRY T, WEISSBRICH B, KANDOLF R, CLEATOR GM and VAN LOON AM (1998) Molecular typing of enteroviruses: Current status and future requirements. Clin. Microbiol. Rev. 11 202-227.

NEALL B (2000) New bottling line for Valvita. SA Food Rev. 27 23-24.

PAVLOV DN, DE WET C, GRABOW WOK and EHLERS MM (2004) Potentially pathogenic features of heterotrophic plate count bacteria isolated from drinking water. Int. J. Food Microbiol.

PAYMENT P, TRUDEL M and PLANTE R (1985) Elimination of viruses and indicator bacteria at each step of treatment during preparation of drinking water at seven treatment plants. Appl. Environ. Microbiol. 49 1418-1428.

PAYMENT P, FRANCO E, RICHARDSON L and SIEMIATYCHI J (1991a) Gastrointestinal health effects associated with the consumption of drinking water produced by point-of-use domestic reverseosmosis filtration units. Appl. Environ. Microbiol. 57 945-948.

PAYMENT P, RICHARDSON L, SIEMIATYCKI J, DEWAR R, EDWARDES M and FRANCO E (1991b) A randomized trial to evaluate the risk of gastrointestinal disease due to consumption of drinking water meeting current microbiological standards. Am. J. Public Health 81 703-708.

PAYMENT P, COFFIN E and PAQUETTE G (1994) Blood agar to detect virulence factors in tap water heterotrophic bacteria. Appl. Environ. Microbiol. 60 1179-1183.

RUSIN, PA, ROSE JB, HAAS CN and GERBA CP (1997) Risk assessment of opportunistic bacterial pathogens in drinking water. Rev. Environ. Contam. Toxicol. 152 57- 83.

SABS (1996) Specification: Bottled Natural Water. SABS 1657: 1996. South African Bureau of Standards, Pretoria.

SABS (2001) Specification: Drinking Water. SABS 241: 2001. South African Bureau of Standards, Pretoria. 
SIMKOVA A and CERVENKA J (1981) Coliphages as ecological indicators of enteroviruses in various water systems. Bull. World Health Org. 59 611-618.

SOBSEY MD, BATTIGELLI DA, HANDZEL TR and SCHWAB KJ (1995) Male-Specific Coliphages as Indicators of Viral Contamination of Drinking Water. American Water Works Association Research Foundation, Denver, CO. $150 \mathrm{pp}$.

STETLER RE (1994) Coliphages as indicators of enteroviruses. Appl. Environ. Microbiol. 48 668-670.

TSAI GJ and YU SC (1997) Microbiological evaluation of bottled uncarbonated mineral water in Taiwan. Int. J. Food Microbiol. 37 137-143.

WARBURTON DW, DODDS KL, BURKE R, JONSTON MA and LAFFEY PJ (1992) A review of the microbiological quality of bottled water sold in Canada between 1981 and 1989. Can. J. Microbiol. 38 12-19.
WARBURTON DW (1993) A review of the microbiological quality of bottled water sold in Canada. Part 2. The need for more stringent standards and regulations. Can. J. Microbiol. 39 158-168.

WARBURTON DW, AUSTIN JW, HARRISON BH and SANDERS G (1998) Survival and recovery of Escherichia coli 0157:H7 in inoculated bottled water. J. Food Prot. 61 948-952.

WARBURTON DW (2000) The microbiological safety of bottled waters. In: Farber JM and Ewen ED (eds.) Safe Handling of Foods. Marcel Dekker Inc. New York.

WHO (1979) Human viruses in water, waste water and soil. WHO Technical Report Series 639. World Health Organization, Geneva.

WHO (1997) Guidelines for Drinking-Water Ouality (2 ${ }^{\text {nd }}$ edn.) Vol 3 : Surveillance and Control of Community Supplies. World Health Organization, Geneva.

WHO (2001) Guidelines for Drinking-Water Quality (2 ${ }^{\text {nd }}$ edn.) Vol 1: Microbiological Methods. World Health Organization, Geneva.

ZAOUTIS T (1998) Enterovirus infections. Pediatr. Rev. 19 183-191. 